The book's Foreword is written by Christian Parenti, a correspondent for The Nation who has a Ph.D. in sociology from the London School of Economics. Co-editor David Gabbard wrote the Introduction ("Canary in the Coal Mine?") that shows how insightful political journalist Hunter S. Thompson was about criminalizing college students who were activists and dissidents on college and university campuses.

Meanwhile, the book is divided into three parts.

Part I, Campus Police, has five articles that include topics about the arrests of student activists, many times after surveillance and instilled fear.

Part II, The Surveilled Campus, also has five articles, which focus on the erosion of privacy for students because of increased and technologically savvy police scrutiny.

Four articles are in Part III, From Defending Public Education to the Occupy Movement, and include discussions about the Occupy Movement that began on Wall Street in New York City, and heavy-handed policing tactics on college campuses.

Nevertheless, this compilation of research articles gives a thorough overview of what has been happening on college and university campuses in Iowa, New York, Minnesota and across the nation since the overall increase in surveillance.

Sandra L. Combs is an Assistant Professor of Multimedia Journalism at Arkansas State University, Jonesboro. The veteran journalist's research interests include race, gender, media and diversity issues.

\title{
The End of Prisons: Reflections from the Decarceration Movement.
}

Edited by Mechtild E. Nagel, and Anthony J. Nocella. New York, N. Y.: Rodopi, 2013. Pp.xv, 248. paperback $\$ 63.86$.

This collection of essays distinguishes itself from similar publications in both its focus and scope in two significant ways. First, while its contributors, as part of the Decarceration Movement, share an interest in prison reform (meaning improved conditions and treatment of incarcerated populations), they are far more concerned with the total abolition of prisons in the U. S. and abroad. Secondly, much like Michelle Alexander's renowned monolith, The New Jim Crow, many of its contributors are also concerned with the logistics of incarceration (i.e. which populations are incarcerated, the implications of incarceration on social justice issues, etc.). However, in The End of Prisons, the prison industrial complex and racial injustice are only the proverbial tip of the prison iceberg.

Perhaps its boldest intervention is to redefine "the carceral," not in terms of brick and mortar buildings with bars, but rather as any site of social control. Drawing from the likes of Michel Foucault, Angela Y. Davis, W. E. B. DuBois, et.al, each selection conceptually enlarges our understanding of "prison," thus enabling each scholar/activists to address myriad overlapping and intersecting social justice issues, their origins, capacity, and potential solutions. The scholarship of the editors, Mechtild 
Nagel and Anthony Nocella, provide the introduction, the first, and the final essays of thirteen chapters, laying the foundation for and framing the remaining scholarship. In the introduction, for example, Nagel and Nocella define an incarcerated subject as any subject who "live[s] under the systems of oppression such as the violence of poverty, racism, sexism, internalized colonialism, ableism, trans- and homophobia" (5). Armed with a scathing critique of social control through the lens of the Occupy Wall Street movement, Nagel and Nocella assert that by examining the way the state responds to social protest, we can more fully understand social control and "dominant oppressive authoritarian positions" (3). For these scholars, social control and incarceration are nearly interchangeable terms and explicitly a function of institutions and larger systems, such as imperialism, capitalism, or sexism.

Other essays of note critique institutions commonly perceived as helpful, such as schools and mental institutions, the link between immigration law and the war on terror, and three essays with a focus on the management of "nonhuman animals" as a kind of prison. The essays on nonhuman animals permit intersectional approaches that reveal interesting links between capitalism and science, and between anthropocentrism and patriarchy.

Largely, The End of Prisons is an engaging, thoughtful, and provocative collaboration, offering interventions within the fields of Social Philosophy and Applied Philosophy, specifically, to Social Justice Studies in general, and most of all, to the burgeoning Decarceration Movement.

Carmen Lanos Williams is an Instructor in English and Philosophy Department at Arkansas State University, Jonesboro and a graduate student at Indiana University's PhD Program in African American and African Diaspora Studies. 